\title{
Bayes' Theorem as a Tool for Better Administration of Employee Discretion
}

\author{
Mirko Pečarič \\ https://doi.org/10.31297/hkju.21.1.2 \\ UDK $\quad 35.08: 342.727$ \\ 35.08 .01 \\ Review scientific paper / pregledni znanstveni rad \\ Received / primljeno: 07.07.2020. \\ Accepted/prihvaćeno: 15.01.2021.
}

The power to choose is not only possible in legal frameworks but also outside of them. So far, informal power has been viewed as the illegal one in the law, although there are many informal, especially personal elements involved in the legal decision-making that are never brought to light. This paper presents a new type of discretion, named employee discretion, and shows a promising approach towards the idea that officials or judges can decide similarly in similar matters, despite their differences in personal backgrounds, cognitive capabilities or emotional variances, commonly known as pre-existing preferences. This can be done if Bayes' theorem is used. This way, subjective preferences could be known to others, while the principles of equality and equity could be put on a higher level.

* Professor Mirko Pečarič, Faculty of Administration, University of Ljubljana, Slovenia (redovni profesor, Fakultet za upravu, Sveučilište u Ljubljani, Slovenija, e-mail: mirko. pecaric@fu.uni-lj.si).

ORCID ID: https://orcid.org/0000-0002-0551-5682 
Keywords: discretion, administrative discretion, employee discretion, Bayes' theorem

\section{Introduction}

The essence of legal discretion is the power to choose (Cane, 2011), the ability to make intelligent decisions (Merriam-Webster, 2019) in a particular situation. It connotes personal qualities such as prudence, receptivity, sensibility, intelligence, carefulness, and good judgement. Legislators should be aware of the level of delegation of discretion to the other two branches of power not only due to the reason of legitimacy but also due to the principle of legal certainty. Bound decision-making reflects the ideal of a mechanistic decision automaton, without any powers of authentic interpretation, in the sense of Montesquieu's judge as "a mouthpiece that reads the letter of the law", as a passive organ of law-application. Such machine-like decision-making is coming to the fore with artificial intelligence or digitalization of governmental processes that challenge human intelligence, but this paper nevertheless starts with a predisposition of the necessity of discretion also in the future: discretion or the possibility to fill open areas with decisions/actions is taken as an unavoidable consequence of the fact that "all legal power, as opposed to duty, is inevitably discretionary to a greater or lesser extent" (Wade \& Forsyth, 2014, p. 259). Because power should not be abused, discretion must be exercised reasonably, in good faith and on proper grounds. In a legal state, discretion has to be authorized by law and used reasonably, but it stands on shaky grounds with the requirement that its usage must be based on clear reasoning, cautious discernment and elaboration of reasons that come uneasily with the personal inspirations, abilities, experiences, mode of choice, mindset and subliminal influences, personal attitudes and actions connected with that (Hardman \& Macchi, 2004; Newell, Lagnado \& Shanks, 2015; Plessner, Betsch \& Betsch, 2011; Plous, 1993; Tversky \& Kahneman, 1974). These elements contradict the discretionary demand for cautious discernment or intelligent decision-making. The rational recognition of the content of norms and their application to the "legally relevant" facts have a complex relationship with people's irrational and subconscious elements.

In this paper, a new form of discretion is presented that includes subliminal preferences that remain hidden under the sophistic, logically well-explained reasons. Legal discretion is focused on choosing the most appro- 
priate course of action among legally predetermined possibilities (not only in adjudication), while this paper presents employee discretion $(\mathrm{ED})^{1}$ based on the following presumptions: i) legal discretion has a lot of (un)known personal elements that operate behind the known ones; and ii) personal elements can be put on a more objective and thus equal ground with the help of Bayes' mathematical theorem. This theorem could be a path not only towards the clearer grounds of reason, care, and discernment but also towards accepting probability as the inevitable element for the management of uncertainty. These presumptions are based on the elaboration of discretion, on its (non)reviewability, on discretion in the public administration, on pre-existing personal preferences that serve as the key to ED, and on Bayes' theorem (as a method by which subjective preferences can be put on a more objective, comparable level), which are presented in the following sections.

\section{Discretion}

Although Aristotle did not speak explicitly about discretion, he describes a wider notion of "practical wisdom" (phrónessis) as the personal ability of good judgement and excellence of character and experiences to prosper in action through giving oneself the appropriate and practical directions concerning human goods (Aristotle, 2004). Practical wisdom is listed among virtues as an example of a mean ${ }^{2}$ state (between unscrupulousness and unworldliness). Its acquisition requires experience and consists of one's ability to see and understand why and what is important in different circumstances. Concerning what is now called effectiveness (to get the right things done) and efficiency (the ability to do things right) (Drucker, 2002), Aristotle calls virtue that makes "the aim right and practical wisdom what makes right the things towards it" (Aristotle, 2004, p. 116). Discretion can be seen also as an expression of fairness. ${ }^{3}$

1 Another type is political discretion (known as the royal prerogative or in France as the actes de gouvernement), with which this paper will not deal.

2 In all cases, the mean relative to us is best (Aristotle, 1992, p. 16).

3 In Rhetoric he speaks about fairness as justice that goes beyond the written law, where the action is undefinable and the law must speak in general terms. In this regard, it is fair "to look not to the law but the legislator and not to the word but the intent of the legislator and not to the action but the deliberate purpose and not to the part but to the whole" (Aristotle, 2007, p. 100). 
For Dicey, the rule of law means the supremacy of regular law as opposed to the influence of arbitrary power, or even of wide discretionary authority on the part of the government (Dicey, 2012). Hayek similarly thought "the discretion left to the executive organs wielding coercive power should be reduced as much as possible" (Hayek, 2006, p. 76). Dworkin distinguishes two types of (weak) discretion, when "for some reason, the standards an official must apply cannot be applied mechanically but demand the use of judgment (or when) ... some official has final authority to make a decision and cannot be reviewed and reversed by any other official" (Dworkin, 1978, pp. 31-32). The strongest type of discretion exists when an official "is simply not bound by standards set by the authority in question" (Dworkin, 1978, p. 32), but this does not mean "he is free to decide without recourse to standards of sense and fairness, but only that his decision is not controlled by a standard furnished by the particular authority" (Dworkin, 1978, p. 33). This is the kind of discretion with which Dworkin is concerned because he - contrary to the positivistic doctrine of (strong) judicial discretion (if a case is not controlled by an established rule, it argues a judge must decide it by exercising discretion) - thinks judges do not make such arbitrary decisions, but rather, settle with something beyond rules: "there must be some principles that count for more than others" (Dworkin, 1978, p. 37). For Dworkin, principles prevail over the absence of rules (discretion).

When using legal discretion, a decision-maker is entitled to decide or act according to a system of rules. Among the most important classical reasons for (weak) discretion is "discretion as policy"; it arises due to the very inability of legislation to put down everything in advance. Another sub-form is "discretion as a choice or as good government", found in the right to good administration ${ }^{4}$ that goes "further than the law, requiring the EU institutions not only to respect their legal obligations but also to be service-minded" (Diamandouros, 2012). Good administration can be understood as more than the law demands; it is not the morality of duty but aspiration as "the morality of the good life, of excellence, of the fullest realization of human powers" (Fuller, 1969, p. 5). Such discretion acts upon personal preferences and operates outside Dworkin's doughnut, outside legal rules. Here first traces of ED can be found, but there is more to say before ED is presented to do justice to the mentioned aspiration. In the next section, the known standards of reviewability of discretion are presented to enable us to go further into its origins.

${ }^{4}$ It was included into the EU Charter of Fundamental Rights at the initiative of the European Ombudsman. 


\section{3. (Non)reviewability of Discretion}

The US Supreme Court's decision ${ }^{5}$ established the legal basis for judicial review of administrative agencies' actions (limited substantive review): "the court must consider whether the decision was based on a consideration of the relevant factors and whether there has been a clear error of judgment ... Although this inquiry into the facts is to be searching and careful, the ultimate standard of review is a narrow one. The court is not empowered to substitute its judgment for that of the agency". A finding is "clearly erroneous" when although there is evidence to support it, the court, upon examination of the entire evidence, is left with the definite and firm conviction that a mistake has been committed. ${ }^{6}$ Review under the clearly erroneous standard is significantly deferential, requiring a "definite and firm conviction that a mistake has been committed". ${ }^{7}$ Discretionary judgement should be based on the full administrative record that a decision-maker has at the time of making his decision. Although such judgement "does not have to meet the substantial-evidence test (used for rulemaking and formal adjudication), the generally applicable standards of $\S 706$ require the reviewing court to engage in substantial inquiry. The presumption of regularity is not to shield actions from a thorough, probing, in-depth review" (Breyer et al., 2006, p. 360), although "clear error" should be such as to go beyond the confines of reason.

Usually, preclusion of judicial review is a very limited exception used only when there is "no law to apply", when agency action is committed to agency discretion by law ( $\$ 701(\mathrm{a})$ APA) or when an agency decision does not abuse discretion, i.e. when its decision not to enforce involves a complicated balancing of multiple factors within its expertise, when an agency refuses to act and thus not exercise its coercive power, i.e. its prosecutorial discretion; the same holds for the cases in which the court has no meaningful criteria against which to judge the agency's exercise of discretion ${ }^{8}$ or when or how the agency allocates funds from a lump-sum appropriation. ${ }^{9}$ The same holds for the cases in which the Congress specifically

${ }^{5}$ Citizens to Preserve Overton Park v. Volpe, 401 U.S. 402 (1971).

${ }^{6}$ United States v. United States Gypsum Co., 333 U.S. 364, 395, (1948).

7 Easley v. Cromartie, 532 U.S. 234, 242, (2001); Fisher v. Tucson Unified Sch. Dist., 652 F.3d 1131, 1136 (9th Cir), (2011).

${ }^{8}$ Heckler v. Chaney, 470 U.S. 821, (1985).

9 Lincoln v. Vigil, 508 U.S. 182, (1993). 
identified determinations that should be committed to agency discretion by law. ${ }^{10}$ Discretion is not unbounded when agency action is not unlawfully withheld or unreasonably delayed. ${ }^{11}$ Discretion must not be fettered (by illegal decisions, legal decisions (res judicata), soft law, contracts, undertakings, representations, and practices by political commitments), transferred (acting under dictation or delegation by a delegate) or constrained (by irrelevant considerations or ignoring the relevant ones, or by improper purposes) (Cane, 2011). Claims against an agency's abuse of discretion are concentrated "in one of four ways: by considering an irrelevant factor, failing to consider a relevant factor, giving improper weight to a relevant factor, or deciding without sufficient evidence" (Saferstein, 1968, p. 368). From the restraint review, courts have also moved towards procedural (based on the proportionality test, the duty of the competent institution to examine carefully and impartially all the relevant aspects/facts of the individual case, the right of the person concerned to make their views known and to have an adequately reasoned decision), while it remains to be seen when a test on evidence-based legislative rationality will be used. The unlimited jurisdiction ${ }^{12}$ is the most intensive ECJ review standard, applied for the assessment of whether the Commission's competition law sanction (fine or penalty payment) is proportionate to the seriousness of the violation of the competition rules. Strict substantive review on proportionality is used by the ECJ in fundamental rights cases, ${ }^{13}$ while a process review of the national margin of appreciation and discretion is used in fulfilling obligations under the European Convention on Human Rights is used. ${ }^{14}$ Depending on the Rules in question, Art. 47. CFR (the right to effective judicial protection) may require a thorough judicial review (Samba Diouf), a very restrained review only (Berlioz), or something in between (Egenberger), while in a process review of the national margins of appreciation and discretion the ECJ assesses whether the legislator's assessment contains a manifest error or constitutes a misuse of power, or whether the authority has manifestly exceeded the limits of its discretion.

\footnotetext{
10 Webster v. Doe, 486 U.S. 592, (1988).

11 Public Citizen Health Research Group v. Chao, 324, 314 F.3d 143 (3d Cir.), (2002).

12 E.g., C-389/10 P - KME Germany and Others v Commission, (2011).

13 E.g., C-293/12 Digital Rights Ireland, (2012).

14 E.g., Case C-320/03 Commission v. Austria, (2005).
} 


\subsection{Insufficient Judicial Guidelines on Discretion}

Discretionary power is not absolute. Limitations are expressed in a variety of different ways, such as by saying that "discretion must be exercised reasonably and in good faith, that relevant considerations only must be taken into account, that there must be no malversation of any kind, or that the decision must not be arbitrary or capricious. They can all be comprised by saying that discretion must be exercised in the manner intended by the empowering Act" (Wade \& Forsyth, 2014, p. 291), but in case-law, there is still no guidance on how an irrelevant factor should not be considered, how failure to consider a relevant one or giving improper weight to a relevant factor can be prevented. Legislators or judges can test only external elements (de internis non judicat preator) of officials' arguments (whether the decision was reasonable, and depending on the importance of the case also vis-ã-vis the intent, consequences and context) and not the latter's minds. Despite the fact that judges test discretion also in the light of the principles of subsidiarity, proportionality, transparency and human rights, they place themselves "in the shoes" of public servants, and consider what they would do if they were in their place. They subjectively decide what is clearly erroneous, how a careful examination or impartial action has been done. They decide based on their intuition, common sense and reason, they explain their decision based on arguments that can be logically sound but still objectively (based on numerical data) false.

\subsection{Soft Law - the Standard of Reviewability v. Discretion}

Here the relation between soft law (SL) and discretion is described because the former can give a deeper view of the latter due to its further details about rules. From these details, a clearer picture of personal thoughts can be revealed. When discretion is not written, SL as its form can offer an insight into an officer's thinking. ${ }^{15} \mathrm{SL}$ is a form of delegation by which a superior (tacitly or explicitly) permits a subordinate to do something. SL is in its nature of delegation the discretionary option to issue or not some form of written or oral instructions. "Whenever one is concerned with constraints on administrative decision-makers, one must consider institu-

15 In the Canadian case, Baker v. Canada (Minister of Citizenship and Immigration, [1999], 2 SCR 817), the immigration officer's notes were taken as the main reasons for the (discriminatory) decision. 
tional as well as individual contexts. Soft law highlights how institutional dynamics and individual judgment combine in the exercise of discretion" (Sossin \& Smith, 2003, p. 874). The origins of SL are - along with the explicit formal possibility in a statute - based also on discretion: " $(w)$ henever an officer has a discretionary power to decide what to do in a particular case, he necessarily has the power to announce how he will exercise that power. Such an announcement may be an interpretative rule, but it may have great value even though, for want of a statutory grant of power, it may lack the force of law" (Davis, 1969, p. 220). "Soft law is a particularly significant window into the relationship between judicial and bureaucratic decision-making. Non-legislative instruments embody the policy choices of decision-making bodies, including the interpretation and application of new judicial standards. Such discretionary standards and guidelines, in turn, are considered as part of the decision-maker's "expertise", which attracts deference from the Court when discretionary decisions are challenged" (Sossin, 2004, p. 91).

SL has, like discretion, similar causes for its existence (due to the new technology, complex social and natural problems, a lack of formal legislative competences, difficulties in a legal procedure or a desire to guarantee flexibility and diversity in the shortest time possible), and with (classical) discretion it shares a similar standard of review, i.e. a manifest error of assessment. Courts usually apply marginal (not full) review that demands intervention only in exceptional circumstances. For the General Court an error of assessment is not manifest "if, in the particular circumstances of the case, it could not have had a decisive effect on the outcome". ${ }^{16}$ ECJ held that "judicial review is limited to manifest errors of assessment as to whether the EU legislature could reasonably have taken the view, first, that, to be implemented, the legal framework which is laid down ... needs only the addition of further detail, without its non-essential elements having to be amended or supplemented and, secondly, that the provisions... require uniform conditions for implementation". ${ }^{17}$

Manifest error in the frame of SL could be treated differently than in the frame of discretion (despite the fact the first interprets the second); here the first presupposes validity of all legal acts (including the discretionary ones), so grave errors like an improper purpose, ignoring relevant considerations or taking irrelevant ones into account, unreasonableness as the

\footnotetext{
16 T-60/05, Ufex and Others v. Commission (2007), para 77.

17 C-427/12, Commission v. Parliament and Council (2014), para 40.
} 
failure to respect general principles of law, infringement of human rights, discrimination, abuse of power or process and hidden motives are illegal, and thus do not fall into consideration of whether such SL is valid. The manifest error could hence in the relation hard law (HL) - SL be divided into manifest error 1 and manifest error 2 (or manifest and less manifest error). The validity of SL in the second frame addresses the ambiguous and disputable errors of facts or disputable errors of judgement, an apparent disregard of facts of the case (an apparent failure to correctly assess legal and material facts, failure to consider factors that could lead to different results or considering irrelevant ones, but they are nevertheless not so grave as in the abuse of power or manifest error 1 frame). Manifest error 2 occurs when interpretation/argumentation could be different than it is. SL with its less manifest error 2 is similar to the above-given conclusion from the previous subsection but can be seen as a further pointer towards ED, where the (unknown) errors, fallacies and cognitive illusions come more to the fore in decision-making. They are seen as a decision's pre-denominators, usually known as pre-existing preferences.

\section{Public Administration as the Portal into ED}

The classical approach to the separation of power is based on trias politi$c a$ (the tripartite approach), but public administration (PA) is nowadays gaining more and more power. Although the regulatory state "applies and extends rule-making, monitoring and enforcement via bureaucratic organs of the state" (Levi-Faur, 2011, p. 14) also to other stakeholders, PA is the most important factor: the vast majority of legislative proposals (above 90\%) are initiated by the government in e.g. the United Kingdom, Croatia, Finland, Hungary, Macedonia, Romania, and Slovenia (Kasemets, 2001). Along with the complexity of discretion itself, this growth of governmental powers vis- $\tilde{a}$-vis the legislative ones calls for a more detailed elaboration of discretion used in the practice of PA. For Hayek, "more and more of the tasks which the man in the street imagines to be the main occupation of the legislators are performed by civil servants. It is largely because the legislatures are preoccupied by what in effect is discretionary administration that the true work of legislation is increasingly left in the hands of the bureaucracy" (Hayek, 1998, p. 30). Legislators cannot foresee various elements and contexts in different cases, and hence make room for PA to fill gaps, weigh interests, balance evidence and decide what is best in a particular situation. Discretion is best known in adminis- 
trative adjudication (as administrative discretion), but there are also other forms of it present in administrative actions.

If the rule of law "means, not that everything is regulated by law, but, on the contrary, that the coercive power of the state can be used only in cases defined in advance by the law and in such a way that it can be foreseen how it will be used" (Hayek, 2006, p. 87), this foreseeability is important in PA as the largest public entity regarding the number of issued legal acts. Restrained judicial scrutiny gives a lot of open space to the executive branch of power that can "do what it wants" as long its reasons are rationally presented in a logical, readable and understandable way that seems as "the most conspicuous and recognizable Orion's constellation in the night sky". Discretion can be along with good interpretation even better understood through the better understanding of officials' behaviour, their everyday (in)actions. They are the ones who apply reason and other elements: they use their will (Kelsen, 2005), but also act on subconscious elements.

Art. 298 and 15 of the TFEU emphasise the open, efficient, independent, transparent and participatory European administration. Undoubtedly these demands stand not only formally but are especially relevant in practice as the most important aspect in which public employees' characteristics come to the fore (this holds true also for the national level). On all levels, citizens' rights should not only be formally declared but also practically implemented. Formal powers are tightly connected with informal considerations; as the latter are applied ex-ante at legal drafting and ex-post at the legal implementation, their modus operandi should be known. These informal dealings are in PA usually known as discretion. To understand this activity of "cautious discernment, prudence or the power of free decision-making" (Garner, 2004, p. 499), which happens "whenever the effective limits on his [a public officer's] power leave him free to choose among possible courses of action or inaction" (Davis, 1979, p. 4), one should understand legal rules are frequently silent on their use, procedure, intent or consequences vis-ã-vis myriad scenarios. In the following two sub-sections, two types of subjective discretion are described to gain a deeper view of ED.

\subsection{Administrative (Informal) Discretion}

Administrative discretion can be present in all of the so far mentioned forms of discretion, be it weak, strong, policy- or expert-based. Judicial 
control has settled around the known approaches or standards of control, but there are things courts so far have not embraced in strict legal frames (legal positivism). Davies in 1969 further invented the notion of discretionary justice in a place where law ends. For him, discretion is not limited to what is legal but includes all that is within the effective limits of the officer's power. His informal discretionary power is the lifeblood of administrative processes and includes functions such as "initiating, prosecuting, negotiating, settling, contracting, dealing, advising, threatening, publicizing, concealing, planning, recommending and supervising" (Davis, 1977, p. 440), while the most awesome discretionary power is the "omnipresent power to do nothing" (Davis \& Pierce, 1994, p. 105). The widely known examples are police's and state prosecution's possibility (not) to initiate procedures, known also as prosecutorial discretion (Shapiro, 1982). Such examples exist, but there is more: based on a thorough examination of reasons pro et contra weak and strong discretion, Vila concludes that "(i)t is not disagreement but the limit to our ability to imagine how things are and to present them in their best light what leads to the need for strong discretion. Surely, limits remain, but to consider that they rule wherever disagreement and controversy rule would suggest disheartening scepticism about the potential of human imagination" (Vila, 2001, p. 205). Davis' informal discretionary power is the closest to this paper's notion of ED; the latter could be seen as an extended, updated version of informal discretion with its emphasis (not on the law, but) on employees as persons, who apply their mental, cognitive functions, mixed with their character to abstract or specific contexts. While the administrative and political discretion is known, ED is not. Because it is practised daily and on an even larger scale and scope than the previous two, it needs to be brought to light.

\subsection{Employee Discretion}

ED is the deeper form of discretion because it does not provide an answer that could be (equally) correct, it does not even respect the system's boundaries and does not provide clear or open criteria to choose among different solutions. It can be imagined simply as all possible human doings at work, as a reflection of various human characters. For ED, there is no obligation to lay down reasons that justify officials' choices; room for choice is not understood as a power, permission or authorisation granted to the official by the law, but it is viewed as a possibility, go-ahead person- 
al endorsement to act or decide when the law does not provide a univocal solution, when the law is silent, when the law does not even widely incorporate/presuppose actions.

ED arises not only from the binary (non-)usage of official competencies, the (in)activation of official powers (that are (un)determined for a specific official position), the interpretation of (un)determined legal notions visà-vis formal goals, legal principles or personal wishes but exhibits itself in all their combinations. ED is about (in)actions within the existing competencies in the light of future solutions and improvements, which are ex-post acknowledged by the management as essential for the agency's operations. ED could be a denominator of the public employee's will to do or not to do something, to give lesser or greater weight to something, it can be present even in cases where an employee does not exercise administrative discretion (but nevertheless does everything to undermine a legal rule, its goal or consequences, without clearly shown abuse of power). It is present also where well-established techniques, procedures or legal standards are enacted (what an employee will do on a particular day, who he will listen to, for how long, what kind of energy will be put in some doing, what usual or unusual means he will use for a specific assignment, to which problem he will give more attention and what weight he will give to arguments, evidence, or what facts he will recognise as (non-)alarming or (not) important. ED depends on many factors that cannot even be enumerated, let alone fully explained or predicted).

Based on such a description, ED fits into legal realism; Holmes (2009) as the founder of this movement has warned of other elements, besides logical thinking, while Frank, who was also familiar with psychology and psychoanalysis, denied the existence of legal rules in advance of an individual judicial decision based on the necessary existence of this personal element, based on which a person acts accordingly (Frank, 1949, p. 138). According to Frank's perception, the quest for absolute legal certainty (as an example of a child-like yearning for fatherly authority) goes towards the impossible legal inflexibility and infallibility. ED can be the other name for the personality that embraces the character, psychological elements, experiences, milieu, logic, skills, intelligence and silliness at the same time, and in all their combinations. For the Nobel laureate Kahneman, the neglect of base rates and insensitivity to the quality of information are common biases of prediction (Kahneman, 2013). The latter part is addressed in the next section, and the former (as the most important part of ED) is addressed in the sixth section. 


\section{Cognitive Elements of ED}

Bad implementation put aside, the first condition of good decision-making is the awareness of cognitive flaws. This is the biggest shortcoming of ED. Human intuition and common sense based on (everyday) experience can fail when something new/different is present. Hume's idea that reason is the slave of our passions (Hume, 2009) got many updates in the primacy of intuition (Baron, 1998; Haidt, 2012; Kahneman, 2013), of actions before reason, reflections and discourse (Kaplan, 2012) based on impulse and desire (Russell, 2015), where demands for common sense are often only calls for a greater use of intuition (Hammond, 1996; Watts, 2011). Heuristics (Tversky \& Kahneman, 1974), overconfidence (Dunning et al., 1990), ex-post rationalisations (Varoufakis, 2002) and other biases muddle reason with emotion; in fact, "there is no inner contrast between emotion and reason: emotion is the main source of motivation steering us towards certain goals; it can steer a considerable power of reason towards the goals that it gives rise to" (Simon, 1997, p. 91). Even more, emotions form in the amygdala (a small, two-sided structure in the temporal lobe of the brain) that causes emotional learning and evaluation, particularly in provoking emotional responses to fear or aggressive stimuli (Adolphs, Tranel \& Damasio, 1998). As people do not make decisions based solely on reason, they should be aware of caveats like the confirmation bias, expost rationalisation, and other systematic errors in thinking. Traditional (and legal) understanding of rational decision-making is at odds with the psychological idea of the primacy of actions and their ex-post rationalisations.

There is a lot of other literature on personal cognitive elements, while the existence of (cognitive) preferences in decision-making can be seen in the following cases: imagine that an officer has to decide on the probability that an inspection will find a violation in a new, suspected case:

Case 1: In 100 inspections, 45 legal violations were found that stood the legal test with remedies in $70 \%$ of cases. Where no remedies were used, these cases still present $5 \%$ of infringements. What is the probability that a new taxpayer violates rules in the inspected area?

Case 2: 5 violations occurred in 365 cases. In the case of violations, inspections had previously correctly assumed the presence of violations in $90 \%$ of cases, and in $10 \%$ of cases, violations were present where inspections did not suspect them. What is the probability that a new case represents a violation in the inspected area? 
Case 3: A worker has been present in working shifts in 142 cases out of 1029, and in 8 cases (out of 19) he was present when violations occurred. Could he be a suspect?

Intuitively, case 1 has lower and case 2 higher probability, while in case 3 the worker is probably a suspect. But is this true? Intuitively yes, rationally no (with the help of Bayes' rule, see the next chapter, probabilities in the cases 1,2 and 3 are 91.97\%,11.1\% and 10.42\%, respectively). ED could in such cases - due to the erroneously determined base rate - consume energy for totally wrong cases. Subjective reasons are present in decision-making. In the above-given lines, ED is described in such a way that the official's discretionary power may be due to the complexity of its use so limited vis-ã-vis formal controls, that the elements of obligation to state (true) reasons or accountability do not even come into the fore. One way to predict the outcome of any future decision is a set of prior decisions in which decision-makers had responded to facts presented to them, alongside with the individual drives, ideological preferences and dislikes in the mind of the concerned. The principle of quadruple reality establishes all parts of reality as a probability. Here comes in handy Bayes' theorem that also consists of four parts, with an additional possibility to calculate probability, being for Cicero (1853) the very guide of life.

\section{Pre-Existing Preferences as the Key to ED}

ED is a living, flexible thing. It is a mix of emotions, reason and courage that can all present themselves in decisions/actions in four ways: true positive, false positive, true negative and false negative. ED is a mix of human (in)actions, values, (ir)rational thinking, human empathy, emotions, the (sub)conscious and other elements that function as priors or base rates that act subliminally to decision-making. These preconceptions as personal factors are also the basic ingredients of judicial decision-making. ${ }^{18}$ Different personal pre-existing preferences can lead to different decisions/actions/conclusions in the same case. Officials should not - from the point of equality and

18 Judges estimate the likelihood (e.g. that a witness tells the truth) "based on previous experience in similar cases ... This pre-inquiry estimate is what is called a "prior probability" or just a "prior". The judge's mind will be unconscious of his having such a prior, and he would be most unlikely to express it in quantitative terms. But it would be there, and it would affect his posterior probability-that is, the probability that he would assign to the witness having testified truthfully" (Posner, 2010, p. 66). 
non-discrimination - proceed according to their own will, private affection or even in bad faith (Weber's sine ira et studio), but on the other hand, it is undeniable that in discretionary judgement are present also personal cognitive and logical capacities, emotions, desires, interests and unconscious prejudices or preconceptions present as the forms of tacit thinking (Polanyi, 2009) juxtaposed to clear analytic and synthetic reasoning.

The letter is influenced not only by childhood background, education, residence and prevalent social beliefs but also by personal character. ED goes prima facie contrary to the established understanding of prohibition of bias or personal affections in legal decision-making. Because the law should not be biased, case-law understandably does not mention personal pre-existing preferences, but they are from a psychological point of view the key into the depths of ED; "good faith" review presupposes the agency has acted in such faith, without bias, prejudice, or unfairness. If courts prima facie do not find these three elements, they do not actively search for them and do not demand that such evidence be provided and hence uphold a discretionary decision. Prior beliefs (base rates or preferences) can be reconciled with the (new) evidence with the help of Bayes' rule that ranks hypotheses based on subjective probability. Personal preconceptions can be thus more "objective" (or easily compared) parts in rational thought.

\section{Bayes' Theorem}

As people always think up to a point also subjectively, based on their personal perspectives, feelings and thoughts, probability can be better established in the subjective Bayesian framework, in which how much we believe something after we have seen the evidence depends not only on what the evidence shows but on our pre-existing preferences (pre-investigation, prior probability or just a prior) or weights that affect our view on evidence or how much we believed in the evidence from the start. After an analysis of nine theories of judicial behaviour (attitudinal, strategic, sociological, economic, organizational, pragmatic, phenomenological and legalist), Posner concluded that Bayesian decision theory can be helpful to understand judicial preconceptions in shaping responses to uncertainty. Understanding does not presuppose also that Bayesian decision theory can be used by other higher instances, as the latter do not possess subjective information of a judge who made a decision. 
Bayes' theorem (BT) is a tool by which a decision-maker - if they want to be more objective - can more effectively use their prior knowledge of conditions that might be related to the event and known facts about the latter to calculate the probability of an event and/or criteria for a more impartial assessment of the validity and reliability of the evidence itself vis-ã-vis all types of scrutiny: manifest error, procedural proportionality (suitability, necessity, and proportionality stricto sensu), limited substantive, or finally substantial review. ${ }^{19}$ The latter was being proclaimed in the case where the US Supreme Court stated that a trial court has not only the power but the obligation to act as a gatekeeper in determining whether an expert's opinion is based on scientific reasoning and methodology. The Court gave a non-exclusive list of four factors that help ascertain whether a theory's or technique's underlying reasoning or methodology is scientifically valid and can be properly applied to the facts at issue: "Including whether the theory or technique in question can be (and has been) tested, whether it has been subjected to peer review and publication, its known or potential error rate, and the existence and maintenance of standards controlling its operation and whether it has attracted widespread acceptance within a relevant scientific community". ${ }^{20}$

BT can give us a clearer base rate and outcome of a person's thinking within the frame of ED when a decision-maker explains the numbers (percentages) used in BT on which he established the probability of an event. If we want to establish that event $A$ arises if $B$ occurs $(A \mid B)$, these mutually exclusive events are multiplied and their result divided by $B$ (because $A \mid B$ cannot occur if $B$ does not occur), so we get Bayes' rule: $P(A \mid B)=P(A)$ $x \mathrm{P}(\mathrm{B} \mid \mathrm{A}) / \mathrm{P}(\mathrm{B}) \cdot{ }^{21}$ If we want to establish the occurrence of event $\mathrm{A}$, we need not only establish that $B$ has occurred, but also than $B$ has not $(\sim)$ occurred: $\mathrm{P}(\mathrm{A})=\mathrm{P}(\mathrm{B}) \times \mathrm{P}(\mathrm{A} \mid \mathrm{B})+\mathrm{P}(\sim \mathrm{B}) \times \mathrm{P}(\mathrm{A} \mid \sim \mathrm{B})$. As $\mathrm{P}(\mathrm{A} \mid \mathrm{B}) / \mathrm{P}(\mathrm{B})$ is equal to $\mathrm{P}(\mathrm{B} \mid \mathrm{A}) / \mathrm{P}(\mathrm{A})$, we get Bayes' theorem as total probability: $\mathrm{P}(\mathrm{A} \mid \mathrm{B})=$ $\mathrm{P}(\mathrm{B} \mid \mathrm{A}) \times \mathrm{P}(\mathrm{A}) / \mathrm{P}(\mathrm{B} \mid \mathrm{A}) \times \mathrm{P}(\mathrm{A})+\mathrm{P}(\mathrm{B} \mid \sim \mathrm{A}) \times \mathrm{P}(\sim \mathrm{A}) .{ }^{22}$ The same, more simply

19 See three examples in the fifth section.

20 C-427/12, Commission v. Parliament and Council (2014); Daubert v. Merrell Dow Pharmaceuticals, Inc. 509 U.S. 579 (1993), para 12-15.

21 Each bit of information the judge receives on that truthfulness would be likely to alter his prior probability, but not erase it; the prior probability would affect the posterior probability as in $\Omega$ [odds] $(\mathrm{H} \mid \mathrm{x})=\mathrm{p}(\mathrm{x} \mid \mathrm{H}) / \mathrm{p}(\mathrm{x} \mid \sim \mathrm{H}) \times \Omega(\mathrm{H})$, the simplest version of Bayes' theorem (Posner, 2010, p. 66).

22 For a longer elaboration of Bayes' theorem, see (Pečarič, 2020). 
presented Bayes' theorem is in the form of a decision tree $(\mathrm{P}=\mathrm{a} \times \mathrm{b} / \mathrm{a} \times \mathrm{b}$ $+(\mathrm{x} d)$ :

Figure 1. Bayes' Theorem as a Decision Tree

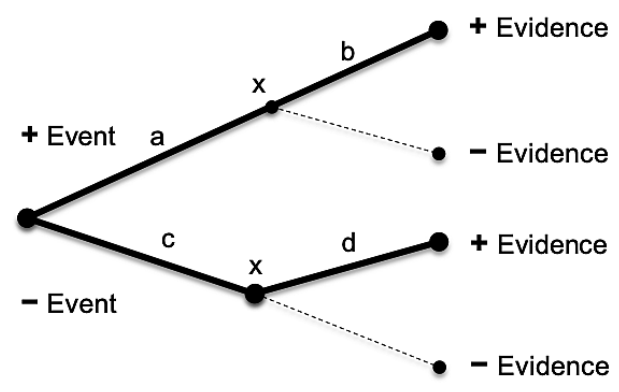

Source: Author.

An individual's classificatory apparatus "not only differs among individuals but can be altered by experience, which varies from individual to individual ... people see (literally and figuratively) things differently, and how they see things, changes in response to changes in the environment" (Posner, 2010, p. 68). People/experts of the same background can form different opinions from the same data (the same holds when reading the same book or watching the same movie), and though this is acceptable in some areas it is unwelcome in the law when rights and obligations should be equally determined in similar cases. By assessing priors, decision-makers can become more comfortable with probability and uncertainty, and at the same time, the "echo chambers" of unfounded claims (or even erroneously established case-law) can be avoided. ${ }^{23}$ ED by using BT resembles Sunstein's well-functioning system of free expression that must meet two requirements: "people should be exposed to materials they would not have chosen in advance (heterogeneity), and many or most citizens should have a wide range of shared experiences (homogeneity)" (Sunstein, 2017, pp. 6-7). BT can lift a person's unconscious intelligence, gut feeling or intuition to a more reflective, deliberate, and analytic level.

23 Consider a situation where an authority has to decide if a foreign migrant should be put into quarantine because he shows symptoms of the Covid-19 disease: among 1000 people, 10 have a virus. Of those 10, eight showed a symptom, and of the 990 not afflicted, 95 did too. What is the probability that this migrant has the virus? By using BT, there is only a $7.78 \%$ probability, so the foreigner should not be placed in quarantine. 
Emotions, beliefs and/or weights (priors) decision-makers have, affect how (much) probability (usually known as evidentiary standards) they assign to actions or consequences. The value of such an approach is in the emphasis on priors that affect the "impartial or apolitical" opinion of a decision-maker. Officials in PA could hence calibrate themselves occasionally to (re)establish at least roughly similar priors to approach similar cases similarly. A personal subjective probability (the priors) can be with BT more objectively determined by an employee himself (as a self-check that can also be easily calculated $)^{24}$ or it can be further advanced when priors are put down on paper and thus become more easily tested also by other people or an agency. ${ }^{25}$ Employees could obtain data from various (statistical) databases maintained by national authorities from particular fields (or from other stakeholders), but it should also be borne in mind, however, that numerical data are not always available for all cases.

BT can nevertheless be seen as an approach that tries to reveal invisible base rates that are nowadays still "hidden" in standards of evidence (e.g., substantial evidence, preponderance of the evidence) and elaborated only with words. When base rates are put down in numbers, a "correct" baseline for the purposes of corrective self-awareness can be additionally test-

24 There are many websites available where the Bayes' calculator can be used (e.g., https://www.richardcarrier.info/bayescalculator.html).

25 In 2004, the court of appeals convicted Lucia de Berk, a nurse from the Juliana Children's Hospital in the Hague, to life imprisonment for 7 murders and 3 attempted murders. A statistician calculated that the probability that something like this would happen by pure coincidence, is less than 1 in 342 million; he put an explicit warning that this does not imply that Lucia is a murderer. If Bayes' rule is used on the relevant numbers of this case (the number of shifts, and incidents for Lucia and others in total for three hospitals, presented in Grünwald (2007), it can be calculated that Lucia had a 53\% probability that an incident would happen in her shift, and others had therefore $47 \%$. Regarding her shifts and incidents, there was an $11.59 \%$ probability, while for all others it was $88.41 \%$. This roughly corresponds to a 1: 9 ratio; based on the math and Gamma distribution Gill (2006) came to a similar conclusion: "(a) modest amount of variation makes the chance that an innocent nurse experiences at least as many incidents as the number Lucia actually did experience, the somewhat unremarkable one in nine" (2006). This would mean that a nurse's probability of being guilty is far away from the beyond reasonable doubt standard. Gigerenzer (2002) describes also a German case of a chimney sweep who was accused of having committed a murder in Wuppertal, Germany. Dr Christian Rittner, a lecturer at the University of Bonn, evaluated the traces of blood as follows: $17.29 \%$ of German citizens share the suspect's blood group, traces of which have been found underneath the fingernails of the murdered woman; $15.69 \%$ of Germans share her blood group that was also found on the suspect's boots; based on a so-called "cross-combination", the expert subsequently calculated an overall probability of $97.3 \%$ that the suspect "can be considered the murderer". Gigerenzer has a contrario calculated that the probability is 1: 2710 (Gigerenzer, 2002, p. 74). Based on Bayes' rule, the probability in this case is $17.29 \%$, and not $97.3 \%$ as the expert witness testified. 
ed along with the present arguments in words. Despite the availability of BT, decision-makers or employees should always bear in mind that the mere statistical probability cannot per se be used as the only evidence in a proceeding without also having other hard evidence available that would give to this probability a "real relation" to probability. Notwithstanding the known method of the mathematical BT (Carrier, 2012; Finkelstein \& Fairley, 1970; Hacking, 2001) in the law, it is rarely used. BT is useful to assess other evidence against statistical and scientific evidence (Kadane, 2008) or to analyse DNA and other evidence (Ayres \& Nalebuff, 2015; Finkelstein \& Fairley, 1970; 1971), but it can serve also for a better elaboration of ED. Results should not be taken for granted, but they could be useful at least for a better (more objective) interpretation of psychological preferences and objective facts. Bayesian approach is used e.g. in medicine and health management (Barbini, Manzi \& Barbini, 2013), but doctors still retain the final say. BT should be thus seen as a helpful tool for the better administration of ED, while the final say would still be on the officials.

\section{Conclusion}

The mere shortcomings of static rules and human characteristics cause the emergence of discretion regardless of its (un)acceptability, with the hope that officials will recognise what is relevant or irrelevant (like a chameleon changes its colour in different environments). Due to the different preferences or base rates persons have, there cannot be one right answer or decision, and neither are objective morality and/or decisions based solely on rules and principles. Subjective (subconscious) preferences also affect conscious decisions. ED is an attempt to bring to light situations that are present in the background of decision-making. "ED is the most "living thing" (a mix of emotions, reason and courage) in the rules, due to its presentation of human (in)actions, values, (ir)rational thinking, human empathy or emotions, the (sub)conscious and other elements" (Pečarič, 2018, p. 6). ED can be evaluated vis-ã-vis the public interest/goals: how much has an official contributed to public goals with his or her actions?

As a complex process that always involves extra-legal elements, ED can be a new step on the line of positivism, but it is divorced from the latter with its irrational and unreasonable elements. ED can be found in soft law, in the executive's material acts, negotiation, communication and constant interactions with co-workers, citizens and interest groups. ED is a mix of reason, values, interests, wishes and through them established facts (ED 
as a lense through which facts are established); the gist is to find how these lenses as pre-existing preferences come to the fore, i.e. how they are engraved in decisions, and how they can be controlled. ED diminishes legal delusions on discretion, shows the weaknesses of present-day legal controls on discretionary judgement, but also proposes a way through which personal elements can be put on similar ground. As for the control on $\mathrm{ED}$, the same holds true for this approach - its further development will be based on officials' personal (in)actions.

\section{References}

Adolphs, R., Tranel, D., \& Damasio, A. R. (1998). The human amygdala in social judgment. Nature, 393(6684), 470-474, https://doi.org/10.1038/30982

Aristotle (1992). Eudemian etbics books I, II, and VIII (M. Woods, Trans.). Oxford, UK: Clarendon Press.

Aristotle (2004). Nicomachean ethics. Cambridge, UK: Cambridge University Press, https://doi.org/10.1093/oseo/instance.00264018

Aristotle (2007). On rhetoric: A theory of civic discourse. New York, Oxford: Oxford University Press.

Ayres, I., \& Nalebuff, B. (2015). The rule of probabilities: A practical approach for applying Bayes' rule to the analysis of DNA evidence. Stanford Law Review, 67(6), 1447-1503, https://doi.org/10.2139/ssrn.2549068

Barbini, E., Manzi, P., \& Barbini, P. (2013). Bayesian approach in medicine and health management. Current Topics in Public Health, doi https://doi. org $/ 10.5772 / 52402$

Baron, J. (1998). Judgment misguided intuition and error in public decision-making. Oxford, UK: Oxford University Press.

Breyer, S. G., Stewart, R. B., Sunstein, C. R., \& Vermeule, A. (2006). Administrative law and regulatory policy: Problems, text, and cases (6th ed.). New York, USA: Aspen Publishers.

Cane, P. (2011). Administrative law. Oxford, UK: Oxford University Press.

Carrier, R. (2012). Proving bistory: Bayes's theorem and the quest for the bistorical Jesus. Amherst, USA: Prometheus Books.

Cicero, M. T. (1853). The treatises of M.T. Cicero: On the nature of the Gods; On divination; On fate; On the Republic; On the laws; and on standing for the consulship (C. D. Yonge, Trans.). London, UK: H. G. Bohn.

Davis, K. C. (1969). Discretionary justice: A preliminary inquiry. Baton Rouge, USA: Louisiana State University Press, https://doi.org/10.1017/s0003055400263612

Davis, K. C. (1977). Administrative law; Cases-text-problems (6 edition). St. Paul, USA: West Pub. Co. 
Davis, K. C. (1979). Discretionary justice: A preliminary inquiry (Fifth printing). Urbana, Chicago, London: University of Illinois Press.

Davis, K. C., \& Pierce, R. J. (1994). Administrative law treatise (3 edition). Boston, USA: Little, Brown.

Diamandouros, P. N. (2012). The European Ombudsman and good administration post-Lisbon. In D. Ashiagbor, N. Countouris \& I. Lianos (Eds.), The European Union after the Treaty of Lisbon (pp. 210-226). Cambridge, UK: Cambridge University Press. doi https://doi.org/10.1017/CBO9781139084338.009

Dicey, A. V. (2012). Introduction to the study of the law of the constitution. San Bernadino, USA: Ulan Press.

Drucker, P. F. (2002). The effective executive. New York, USA: HarperCollins.

Dunning, D., Griffin, D. W., Milojkovic, J. D., \& Ross, L. (1990). The overconfidence effect in social prediction. Journal of Personality and Social Psychology, 58(4), 568-581, doi https://doi.org/10.1037/0022-3514.58.4.568

Dworkin, R. (1978). Taking rights seriously (Fifth Printing edition). Cambridge, UK: Harvard University Press.

Finkelstein, M. O., \& Fairley, W. B. (1970). A Bayesian approach to identification evidence. Harvard Law Review, 83(3), 489-517, https://doi.org/10.2307/1339656

Finkelstein, M. O., \& Fairley, W. B. (1971). The continuing debate over mathematics in the law of evidence: A comment on "Trial by mathematics". Harvard Law Review, 84(8), 1801-1809, https://doi.org/10.2307/1339569

Frank, J. (1949). Law and the modern mind. London, UK: Stevens and Sons.

Fuller, L. L. (1969). The morality of law. New Haven \& London: Yale University Press.

Garner, B. A. (2004). Black's Law Dictionary (8th edition). St. Paul, USA: Thomson West.

Gigerenzer, G. (2002). Adaptive thinking: Rationality in the real world. New York, Oxford: Oxford University Press, https://doi.org/10.1016/s0001-6918(02)00046-x

Gill, R. D. (2006). Lucia: Killed by innocent beterogeneity. Mathematical Institute, Leiden University. Retrieved from http://www.math.leidenuniv.nl/ gill/hetero.pdf

Hacking, I. (2001). An introduction to probability and inductive logic. Cambridge, New York: Cambridge University Press.

Haidt, J. (2012). The righteous mind: Why good people are divided by politics and religion. New York, USA: Pantheon Books, https://doi.org/10.1007/s12115012-9622-0

Hammond, K. R. (1996). Human judgment and social policy: Irreducible uncertainty, inevitable error, unavoidable injustice. Oxford, UK: Oxford University Press.

Hardman, D., \& Macchi, L. (2004). Thinking: Psychological perspectives on reasoning, Judgment and decision making. Chichester, UK: John Wiley \& Sons, https://doi.org/10.1002/047001332x

Hayek, F. A. (1998). Law, legislation and liberty: A new statement of the liberal principles of justice and political economy. London, New York: Routledge, https://doi. org/10.4324/9781315887685 
Hayek, F. A. (2006). The road to serfdom. London, New York: Routledge.

Holmes, O. W. J. (2009). The path of the law. New York, USA: The Floating Press.

Hume, D. (2009). A treatise of buman nature. Auckland, New Zealand: The Floating Press.

Kadane, J. B. (2008). Statistics in the law: A practitioner's guide, cases, and materials. Oxford, UK: Oxford University Press.

Kahneman, D. (2013). Thinking, fast and slow (Reprint edition). New York, USA: Farrar, Straus and Giroux.

Kaplan, J. M. (2012). Rational decision making: Descriptive, prescriptive, or explanatory? In A. Nelson (Ed.), A companion to rationalism (pp. 425-449). Oxford, UK: John Wiley \& Sons, https://doi.org/10.1002/9780470996904.ch23

Kasemets, A. (2001). Impact assessment of legislation for parliament and civil society: A comparative study. Proceedings of ECPRD Seminar. Retrieved from https:// www.riigikogu.ee/rva/ecprd/04_part_2.pdf

Kelsen, H. (2005). Pure theory of law. Clark: The Lawbook Exchange, Ltd.

Levi-Faur, D. (2011). The Odyssey of the regulatory state. Episode one: The rescue of the welfare state. Jerusalem Papers in Regulation \& Governance Working Paper No. 39. Retrieved from http://regulation.huji.ac.il/papers/jp39.pdf

Merriam-Webster (2019). Thesaurus results for discretion. Retrieved from https:// www.merriam-webster.com/thesaurus/discretion

Newell, B. R., Lagnado, D. A., \& Shanks, D. R. (2015). Straight choices: The psychology of decision making. London, New York: Psychology Press.

Pečarič, M. (2018). Employee discretion - The mother of all discretions. Cogent Social Sciences, 4(1), 1-14, https://doi.org/10.1080/23311886.2018.1526661

Pečarič, M. (2020). Confirmation of standards of proof through Bayes Theorem. Archiv Für Rechts- Und Sozialphilosopbie, 106(4), 532-553, https://doi. org/10.25162/arsp-2020-0026

Plessner, H., Betsch, C., \& Betsch, T. (2011). Intuition in judgment and decision making. New York, USA: Psychology Press.

Plous, S. (1993). The psychology of judgment and decision making. New York, USA: McGraw-Hill Education.

Polanyi, M. (2009). The tacit dimension. London, UK: University of Chicago Press.

Posner, R. A. (2010). How judges think. Cambridge, Mass.: Harvard University Press.

Russell, B. (2015). Why men fight: A method of abolishing the international duel (Kindle Edition). Morrisville: Lulu Press, Inc.

Saferstein, H. (1968). Nonreviewability: A functional analysis of "Committed to agency discretion". Harvard Law Review, 82(2), 367-398, https://doi. org/10.2307/1339230

Shapiro, M. (1982). Administrative discretion: The next stage. The Yale Law Journal, 92, 1487-1522.

Simon, H. A. (1997). Administrative behavior (4th Edition). New York, USA: Free Press. 
Sossin, L. (2004). The rule of policy: Baker and the impact of judicial review on administrative discretion. In D. Dyzenhaus (Ed.), The unity of public law (pp. 87-112). Oxford, Portland: Hart Publishing, https://doi.org/10.5040/9781472559555.ch004

Sossin, L., \& Smith, C. W. (2003). Hard choices and soft law: Ethical codes, policy guidelines and the role of the courts in regulating government. Alberta Law Review, 40, 867-893, https://doi.org/10.29173/alr1344

Sunstein, C. R. (2017). Republic: Divided Democracy in the Age of Social Media. Princeton, USA: Princeton University Press, https://doi.org/10.1086/696988

Tversky, A., \& Kahneman, D. (1974). Judgment under uncertainty: Heuristics and biases. Science, 185(4157), 1124-1131, https://doi.org/10.1126/science.185.4157.1124

Varoufakis, Y. (2002). Foundations of economics: A beginner's companion. London, New York: Routledge.

Vila, M. I. (2001). Facing judicial discretion: Legal knowledge and right answers revisited. Dordrecht, Netherlands: Springer Science \& Business Media.

Wade, W., \& Forsyth, C. (2014). Administrative law (11 edition). Oxford, UK: Oxford University Press.

Watts, D. J. (2011). Everything is obvious: Once you know the answer. New York, USA: Crown Publishing Group, https://doi.org/10.1017/s0003975612000379

\section{Court or administrative decisions}

Citizens to Preserve Overton Park v. Volpe: The Supreme Court of the United States, 401 U.S. 402, 1971.

United States v. United States Gypsum: The Supreme Court of the United States, Co., 333 U.S. 364, 395, 1948.

Easley v. Cromartie: The Supreme Court of the United States, 532 U.S. 234, 2001.

Daubert v. Merrell Dow Pharmaceuticals: The Supreme Court of the United States, 509 U.S. 579, 1993.

Fisher v. Tucson Unified School Dist.: Court of Appeals for the Ninth Circuit, 652 F.3d 1131, 1136, 2011.

Heckler v. Chaney: The Supreme Court of the United States, 470 U.S. 821, 1985.

Lincoln v. Vigil, The Supreme Court of the United States, 508 U.S. 182, 1993.

Webster v. Doe, The Supreme Court of the United States, 486 U.S. 592, 1988.

Public Citizen Health Research Group v. Chao, United States Court of Appeals, Third Circuit, 324, 314 F.3d 143, 2002.

KME Germany and Others v Commission: CJEU, C-389/10 P, 2011.

Digital Rights Ireland: CJEU, C-293/12, 2012.

Commission v. Austria: CJEU, C-320/03, 2005. 
Commission v. Parliament and Council: CJEU, C-427/12, 2014.

Ufex and Others v. Commission: The Court of First Instance, T-60/05, 2007.

\section{BAYES' THEOREM AS A TOOL FOR BETTER ADMINISTRATION OF EMPLOYEE DISCRETION}

\section{Summary}

This paper presents a new form of discretion that deals with subliminal (personal) preferences, which are present in discretionary decision-making (where the mental, cognitive functions of public servants, mixed with their character and "dressed" with sophistic, logically well-explained and legally allowed reasons are present). This paper presents employee discretion that could be a denominator of the public employees' will to do or not to do something, to give lesser or greater weight to something. The power to choose is hence not only possible in legal frameworks but also outside of them. So far, informal power has been viewed in the law as the illegal one, although there are many informal, especially personal elements involved in the legal decision-making that are never brought to light. This paper offers a promising approach to bow decisions can be similar in similar matters, despite their differences in personal backgrounds, cognitive capabilities or emotional variances. This can be done if Bayes' theorem is used. Probability can bere be established based on how much we believe something after we have seen the evidence; this depends not only on what the evidence shows but also on our pre-existing preferences (pre-investigation, prior probability or just a prior) or weights that affect our view on evidence or how much we believed in the evidence from the start. By assessing priors, decision-makers can become more comfortable with probability and uncertainty, and at the same time, the "echo chambers" of unfounded claims can be avoided. This way, subjective preferences could be known to others, while the principles of equality and equity could be raised to a bigher level. Further development of employee discretion is based on the same grounds as this type of discretion - on our personal (in)actions.

Keywords: discretion, administrative discretion, employee discretion, Bayes' theorem 


\title{
BAYESOV TEOREM KAO ALAT ZA BOLJE UPRAVLJANJE PROSTOROM SLOBODNOG ODLUČIVANJA JAVNIH SLUŽBENIKA
}

\begin{abstract}
Sažetak
U radu se analizira novi oblik slobodnog odlučivanja koji se temelji na podsvjesnim (osobnim) preferencijama koje se pojavljuju u slobodnom odlučivanju (u kojem su intelektualne, odnosno kognitivne funkcije javnib službenika pomiješane s njihovom osobnošću presvučene sofisticiranim, logički lako objašnjivim $i$ pravno dopuštenim razlozima). Prostor slobodnog odlučivanja može biti nazivnik volje javnog službenika da nešto učini ili ne učini ili da nečemu dade manju ili veću težinu. Moć odabira je moguća u pravnim okvirima ali i izvan njib. Dosad se u pravu neformalna moć smatrala nezakonitom, premda su mnogi neformalni, osobito osobni elementi o kojima se nikad ne govori uključeni u donošenje odluka u pravu. Radom se nastoji razviti takav pristup koji bi osigurao da u sličnim stvarima odluke budu slične usprkos razlikama u osobnim pozadinama, kognitivnom kapacitetu ili emocionalnim varijacijama, $i$ to na temelju Bayesovoga teorema. Moguće je utvrditi vjerojatnost da će čovjek nešto vjerovati nakon što vidi dokaze; to ovisi o tome što pokazuju dokazi i kakve su njegove prethodne sklonosti (prethodna saznanja, prethodna vjerojatnost ili prethodna uvjerenja) ili ponderi koji utječu na njegov pogled na dokaze ili vjeru koju im pridaje na početku. Spoznajući svoja preduvjerenja donositelji mogu mirnije donositi odluke u uvjetima vjerojatnosti $i$ neizvjesnosti, a u isto vrijeme mogu se izbjeći odjeci neutemeljenib prigovora. Na taj se način mogu osobne preferencije donositelja odluke učiniti poznate drugima, a načela jednakosti $i$ pravednosti mogu se podići na višu razinu. Dalinji razvoj prostora slobodnog odlučivanja javnib službenika temelji se na istom temelju kao i taj tip slobodnog odlučivanja - na čovjekovim osobnim (ne)djelovanjima.

Ključne riječi: slobodno odlučivanje, upravna diskrecija, prostor slobodnog odlučivanja javnib službenika, Bayesov teorem

